\title{
PROSPEK PENGEMBANGAN PERKEBUNAN KARET (Hevea brasiliensis) RAKYAT DI DESA MARGAHAYU KECAMATAN LOA KULU KABUPATEN KUTAI KARTANEGARA
}

\author{
(Prospect of Development of Rubber Plantation (Hevea brasiliensis) of People In Margahayu \\ Village, Loa Kulu Sub-District, Kutai Kartanegara District)
}

Rita Mariati, Tetty Wijayanti, Heru Marsa'id

Jurusan Agribisnis, Fakultas Pertanian, Universitas Mulawarman Samarinda

Email : rita.mariati@yahoo.com

Article Submitted : 05-01-2020

Article Accepted : 10-02-2020

\begin{abstract}
Rubber plants are one of the important plantation commodities in Kutai Kartanegara Regency, both as a source of income, employment opportunities and driving new economic centersin East Kalimantan. However,the low productivity of rubber plants caused many rubber farmers to switch to other sectors. The purpose of this study is to identify internal and external factors, as well analyzing the prospect of developing rubber farming in Margahayu Village. Research has been carried out from July to August 2018 in Margahayu Village, Loa Kulu District, Kutai Kartanegara District. The research method used was surveys and interviews. The location was determined by purposive sampling. Data collected in this study are primary and secondary data. Data collection method is done by observation, direct interviews with respondents and library studies. Data were analyzed using SWOT analysis. The results showed that the most appropriate alternative was the SO strategy (Strength and Opportunity), because the strategy had the highest score of 4.32. The development of rubber farming in Margahayu Village can be done with the following alternative strategies: The use of superior clone seeds to increase the productivity of rubber crops, establish cooperation with the government or the private sector for the development of rubber plantations, strengthen the information system among members of farmer groups.
\end{abstract}

Keywords: Prospect, Farming, Rubber

\section{PENDAHULUAN}

Dalam era perdagangan bebas sub sektor perkebunan mempunyai peranan yang strategis dalam pembangunan nasional, terutama di dalam meningkatka pendapatan dan kesejahteraan rakyat, penerimaan devisa negara, penyediaan lapangan kerja, perolehan nilai tambah dan daya saing, pemenuhan kebutuhan konsumsi dalam negeri, bahan baku industri dalam negeri serta optimalisasi pengelolaan sumber daya alam secara berkelanjutan. Upaya pengembangan komoditas tersebut diperlukan bukan hanya untuk meningkatkan kuantitas produk, melainkan disertai peningkatan kualitas, keamanan, kontinuitas produksi dengan tingkat harga yang kompetitif sehingga mampu bersaing di pasar internasional. Salah satu komoditas perkebunan yang ada di Indonesia adalah karet.

Tanaman karet (Hevea brasiliensis) merupakan sumber utama bahan tanaman karet alam dunia. Tanaman karet di Kalimantan Timur merupakan komoditi tradisional yang sudah relatif lama diusahakan sebagai perkebunan rakyat, namun karena pengaruh harga yang berfluktuasi sangat tajam usaha perkaretan 
beberapa waktu yang lalu sempat ditinggalkan oleh petani perkebunan untuk beralih kepada usaha lain yang dianggap lebih menguntungkan.

Berdasarkan data dari Dinas Perkebunan Kalimantan Timur tahun 2018, luas areal pertanaman karet tercatat seluas 116.869 ha yang terdiri dari areal Perkebunan Rakyat 93.908 ha, Perkebunan Besar Negara (PBN)sebesar 399 ha dan Perkebunan Besar Swasta (PBS) 22,562 ha dengan produksi berjumlah 62.106 ton lump. Produk tersebut pada umumnya dipasarkan ke Banjarmasin untuk kebutuhan pabrik Crumb Rubber.

Pusat pertanaman karet terbesar berada di Kabupaten Kutai Barat (Kecamatan Melak dan Barong Tongkok) yang dikembangkan oleh petani pekebun melalui proyek TCSSP bantuan dari Bank Pembangunan Asia (Asian Development Bank). Areal penanaman karet lainnya yang cukup luas berada di Kebupaten Kutai Kartanegara berada di Kecamatan Kota Bangun, Marang Kayu, Samboja dan Muara Badak dan Loa Kulu.

Pengembangan tanaman karet di Desa Margahayu Kecamatan Loa Kulu pada tahun 2016 merupakan bantuan dari pemerintah Kabupaten Kutai Kartanegara berupa 100 bibit karet melalui pola ekstensifikasi di lahan seluas 200 ha yang dikelola 3 kelompok tani sebagai perkebunan rakyat dengan produktivitas yang masih di bawah PBN maupun PBS.

Tujuan penelitian ini adalah :

1. Mengidentifikasi faktor-faktor internal yang menjadi kekuatan, kelemahan, perkebunan karet rakyat di Desa Margahayu

2. Mengidentifikasi faktor-faktor eksternal yang menjadi peluang dan ancaman perkebunan karet rakyat di Desa Margahayu

3. Menganalisis prospek pengembangan perkebunan karet rakyat di Desa Margahayu

\section{METODE PENELITIAN}

\section{Waktu dan Tempat}

Penelitian dilaksanakan dari bulan Agustus sampai dengan Desember 2018. Lokasi penelitian di Desa Margahayu Kecamatan Loa Kulu Kabupaten Kutai Kartanegara.

\section{Metode Pengambilan Data}

Data yang digunakan dalam penelitian ini adalah dengan menggunakan data primer dan data sekunder. Data Primer adalah data yang diperoleh dengan pengamatan langsung kelapangan dan mengadakan wawancara yaitu melakukan komunikasi langsung dengan petani karet di Desa Margahayu Kecamatan Loa Kulu Kabupaten Kutai Kartanegara dengan menggunakan daftar pertanyaan (questioner) yang disusun sesuai dengan masalah dan tujuan penelitian. Data sekunder adalah data yang diperoleh dari studi kepustakaan, instansi terkait, Badan Pusat Statistik dan sumber lain yang dapat menunjang penelitian.

\section{Metode Pengambilan Sampel}

Metode penelitian yang dilakukan menggunakan metode purposive sampling. Berdasarkan data yang diperoleh dari Kantor Desa Margahayu bahwa di Desa Margahayu terdapat 3 kelompok tani karet yaitu kelompok tani Datok Tiro, kelompok tani Hidup Baru dan kelompok tani Sumber Jaya dengan jumlah anggota 238 orang. Teknik pengambilan sampel menggunakan rumus Slovin:

$$
n=\frac{N}{1+N e^{2}}
$$

Keterangan :

$$
\begin{aligned}
\mathrm{n} & =\text { Ukuran sampel } \\
\mathrm{N} & =\text { Ukuranpopulasi } \\
\mathrm{e} & =\text { Batas toleransi kesalahan (error } \\
& \text { tolerance) }
\end{aligned}
$$

Dalam penelitian ini peneliti menggunakan presisi 15\%. Sehingga berdasarkan persamaan rumus di atas, jumlah sampel yang diperoleh adalah sebanyak 37 responden petani dan 
responden pendukung dari Dinas perkebunan Kutai Kartanegara, UPT Perkebunan Loa Kulu dan Kepala Desa Margahayu masing-masing 1 orang. Sehingga total sampel sebanyak 40 orang.

\section{Definisi Variabel dan Pengukurannya}

Pengertian yang lebih jelas mengenai hal yang diteliti dapat dijabarkan sebagai berikut :

1. Prospek adalah gambaran umum tentang usaha yang akan dijalankan di masa mendatang yang menguntungkan

2. Faktor internal adalah segala sesuatu /subjek yang berasal dari dalam objek yang keberadaannya mempengaruhi dinamika perkembangan objek tersebut. Subjek ini terdiri dari kekuatan dan kelemahan.

3. Faktor eksternal adalah segala sesuatu dari luar yang harus dihadapi objek dan keberadaannya mempengaruhi dinamika perkembangan objek tersebut, terdiri dari peluang dan ancaman.
4. Kekuatan adalah sumber daya atau keunggulan yang relatif terhadap pesaing dan kebutuhan pasar.

5. Kelemahan adalah keterbatasan atau kekurangan dalam sumber daya atau kemapuan yang mengahalangi kinerja objek.

6. Peluang adalah situasi menguntungkan yang berasal dari luar .

7. Ancaman adalah rintangan-rintangan utama bagi posisi sekarang atau yang diinginkan objek.

\section{Analisis Data}

Data yang diperoleh dianalisis menggunakan pendekatan SWOT. Untuk menyusun faktor-faktor strategi dibuat matrik SWOT yang dapat menggambarkan secara jelas bagaimana peluang dan ancaman eksternal yang dihadapi perusahaan dapat disesuaikan dengan kekuatan dan kelemahan yang dimiliki. Matrik ini dapat menghasilkan empat kemungkinan alternatif strategi.

Tabel 1. Matrik SWOT

\begin{tabular}{lccc}
\hline Internal & Eksternal & Opportunities & Threats \\
\hline Strengths & SO & ST \\
Weaknesses & WO & WT \\
\hline Stmer & &
\end{tabular}

Sumber : Rangkuti, 2015

Keterangan :

1. Strategi SO merupakan strategi dalam rangka menggunakan kekuatan internal untuk memanfaatkan atau menangkap peluang eksternal.

2. Strategi ST merupakan strategi dalam rangka menggunakan kekuatan internal untuk menghadapi ancaman eksternal.

3. Strategi WO merupakan strategi dalam rangka meminimalkan kelemahan untuk memanfaatkan atau menangkap peluang eksternal.

4. Strategi WT merupakan strategi meminimalkan kelemahan sekaligus menghindari ancaman.

Sebelum menggunakan matrik SWOT terlebih dahulu harus menentukan faktor internal dan eksternal yang merupakan kekuatan, kelemahan, peluang dan ancaman dengan memberikan bobot, rating atau skala, bobot $\mathrm{x}$ rating (skor).

Tabel 2. Faktor Internal dan Eksternal

\begin{tabular}{llcc}
\hline Faktor-Faktor Strategi & Bobot & Rating & Bobot x Rating \\
Internal dan Eksternal & & & \\
\hline Kekuatan/strengths & & \\
Kelemahan/weaknesses & & \\
\hline
\end{tabular}


Peluang/opportunities

Ancamanan/thareats

Total

Sumber : Rangkuti, 2015

Keterangan

1. Menentukan 5-10 faktor internal dan eksternal

2. Masing-masing faktor diberi bobot dengan skala mulai 1,0 ( paling penting) sampai 0,0 (tidak penting) berdasarkan pengaruh faktor-faktor tersebut terhadap strategi perusahaan

3. Rating untuk masing-masing faktor dihitung dengan memberi skala mulai dari 4 (outstanding) sampai dengan 1 (poor). Berdasarkan pengaruh faktor tersebut terhadap kondisi perusahaan. Variabel yang bersifat positif (semua variabel yang masuk kategori kekuatan) diberi nilai mulai +1 sampai dengan +4 (sangat baik). Untuk semaua variabel yang masuk dalam peluang (bila peluang sangat besar diberi nilai +4 dan peluang kecil diberi nilai+1). Sedangkan variabel yang bersifat negatif (Semua variabel kelemahan dan anacaman), bila ancaman atau kelemahan sangat besar ratingnya 1 dan bila ratingnya sedikit atau jauh dari rata-rata diberi nilai 4 , pada kolom 3.

4. Mengalikan bobot pada kolom 2 dengan rating kolom 3 memperoleh faktor pembobot dalam kolom 4, hasil berupa skor pembobot untuk masingmasing faktor yang dinilai bervariasi mulai dari 4,0 (outstanding) sampai 1,0 (poor).

5. Skor pembobot (pada kolom 4) dijumlahkan, untuk memperoleh total skor pembobot bagi perusahaan yang bersangkutan. Nilai total ini menunjukkan bagaimana perusahaan tertentu bereaksi terhadap faktor strategis internal dan eksternal.

\section{HASIL DAN PEMBAHASAN}

Desa Margahayu terletak pada ketinggian $50 \mathrm{mdpl}$, dengan luas wilayah 13,3 $\mathrm{km}^{2}$. Wilayah Desa Margahayu merupakan daerah yang dikelola oleh pemerintah ex transmigrasi, yang awalnya kawasan hutan PT. ITCI yang telah dialihkan sebagai usaha pertanian dan perumahan dengan kemiringan $10-35 \%$ dan sebagian besar berbukit, bergelombang, landai dan datar. Jarak Desa Margahayu dengan ibu kota Kabupaten Kutai Kartanegara dapat ditempuh kurang lebih 32 $\mathrm{km}$ dengan waktu tempuh ke ibu kota Kecamatan dengankendaraan bermotor selama 1 jam.

Penduduk Desa Margahayu pada tahun 2018 berjumlah 3.412 jiwa yang terdiri dari 1.768 jiwa pria dan 1.644 jiwa wanita. Mata pencaharian utama penduduk Desa Margahayu adalah petani.

\section{Identifikasi Responden}

Responden dalam penelitian ini ditentukan secara sengaja dan terdiri dari berbagai pihak agar dapat melihat dari berbagai sudut pandang, diantaranya: Dinas Perkebunan Kabupaten Kutai Kartanegara, UPT Perkebunan Loa Kulu, Kepala Desa Margahyu, dan 37 orang petani karet, sehingga jumlah responden adalah 40 orang. Umur responden pada rentang umur 51-60 tahun masih termasuk dalam usia produktif, hal ini sangat menguntungkan karena tersedianya tenaga kerja untuk perkebunan karet. Tingkat pendidikan yang ditempuh responden paling banyak berada pada tingkatan SD sebanyak $64,86 \%$ atau 24 jiwa.

\section{Gambaran Umum Awal Mula Tanaman Karet di Kenalkan di Desa Margahayu}

Tanaman karet di Desa Margahayu pertama kali ditanam pada tahun 1986 di perusahaan yang bernama PT. Hasfarm 
Product Ltd. Awalnya perusahaan ini menanam kakao dan kopi akan tetapi dikarenakan kakao dan kopi terkena penyakit yang mengakibatkan perusahaan merugi sehingga beralih ketanaman karet. Karet mulai ditanam oleh masyarakat Desa Margahayu pada tahun 2009, tanaman karet yang ditanam awalnya menggunakan bibit cabutan atau bibit dari tanaman karet yang ada diperusahaan Hasfarm, pada tahun 2009 kelompok tani yang bernama Karya Manunggal Jaya yang berjumlah 38 orang mulai dibentuk hal ini dilakukan untuk mendapatkan bantuan bibit karet dari Dinas Perkebunan sebanyak 2000 bibit karet. Bibit yang didapatkan langsung dibagikan kepada anggota kelompok Karya Manunggal Jaya, karena bibit yang dibagikan kurang mencukupi bila di tanam pada lahan yang dimiliki oleh petani.

Tabel 1. Jumlah Produksi dan Produktivitas Karet di Kecamatan Loa Kulu tahun 2013 -2017

\begin{tabular}{|c|c|c|c|c|c|c|c|}
\hline \multirow[t]{2}{*}{ No } & \multirow[t]{2}{*}{ Tahun } & \multicolumn{3}{|c|}{ Luas Areal (ha) } & \multirow{2}{*}{$\begin{array}{l}\text { Jumlah } \\
\text { (ha) }\end{array}$} & \multirow{2}{*}{$\begin{array}{l}\text { Produksi } \\
\text { (Ton) }\end{array}$} & \multirow{2}{*}{$\begin{array}{l}\text { Produktivitas } \\
\left(\mathrm{kg} / \mathrm{ha}^{-1}\right)\end{array}$} \\
\hline & & TBM & TM & TTM/TR & & & \\
\hline 1 & 2013 & 9.537 & 4.785 & 682 & 14.824 & $13.426,62$ & 2.823 \\
\hline 2 & 2014 & $10.114,94$ & $5.666,84$ & 707,25 & $16.486,03$ & $9.206,51$ & 1.625 \\
\hline 3 & 2015 & $10.223,84$ & $6.548,20$ & $1.228,25$ & $18.000,29$ & $9.083,61$ & 1.387 \\
\hline 4 & 2016 & $10.700,59$ & $6.623,95$ & $1.269,75$ & $18.594,29$ & $7.098,03$ & 1.072 \\
\hline 5 & 2017 & $9.999,34$ & $6.999,95$ & $1.288,45$ & $18.287,74$ & $16.129,26$ & 2.365 \\
\hline
\end{tabular}

Sumber : Dinas Perkebunan Kutai Kartanegara, 2017

Identifikasi Faktor Eksternal dan Internal

Berdasarkan identifikasi dari kondisi eksternal perkebunan karet rakyat di Desa Margahayu, dapat diketahui informasi tentang peluang dan ancaman yang ada pada usahatani karet, berikut ini faktor eksternal disajikan pada Tabel 4. Nilai Rating adalah keterangan untuk mengklarifikasikan kekuatan pada masing-masing faktor. Keterangan angka pada Faktor Peluang dan Ancaman : (1) Angka 4 adalah sangat kuat; Angka 3 adalah agak kuat; Angka 2 adalah agak lemah; dan angka 1 adalah sangat lemah.

Tabel 4. Faktor Peluang Analisis Lingkungan Eksternal

\begin{tabular}{|c|c|c|c|c|c|}
\hline \multirow[b]{2}{*}{ No } & \multirow[b]{2}{*}{ Peluang } & \multicolumn{2}{|c|}{ Nilai Rating } & \multirow[b]{2}{*}{2} & \multirow[b]{2}{*}{1} \\
\hline & & 4 & 3 & & \\
\hline 1 & Permintaan pasar & $\sqrt{ }$ & & & \\
\hline 2 & $\begin{array}{l}\text { Tersedianya jenis bibit dengan } \\
\text { produktivitas tinggi }\end{array}$ & & $\sqrt{ }$ & & \\
\hline 3 & Dukungan Permerintah & & $\sqrt{ }$ & & \\
\hline 4 & Kesempatan Bermitra & & $\sqrt{ }$ & & \\
\hline \multirow[t]{2}{*}{5} & Ketersediaan Teknologi & & $\sqrt{ }$ & & \\
\hline & Ancaman & 4 & 3 & 2 & 1 \\
\hline$\overline{1}$ & Alih fungsi lahan & & & $\sqrt{ }$ & \\
\hline 2 & $\begin{array}{l}\text { Harga pupuk dan herbisida yang mahal } \\
\text { Perubahan iklim }\end{array}$ & $\sqrt{ }$ & & & \\
\hline 3 & Gangguan hama dan penyakit & & $\sqrt{ }$ & & \\
\hline 4 & Harga karet tidak stabil & & & $\sqrt{ }$ & \\
\hline 5 & & & $\sqrt{ }$ & & \\
\hline
\end{tabular}

Sumber : Data primer diolah, 2019

Berdasarkan identifikasi dari kondisi eksternal perkebunan karet rakyat di Desa 
Margahayu, dapat diketahui informasi tentang peluang dan ancaman yang tersaji pada Tabel 5. Nilai Rating adalah

keterangan untuk mengklarifikasikan kekuatan pada masing-masing faktor.

Tabel 6. Faktor Kekuatan Analisis Lingkungan Internal

\begin{tabular}{|c|c|c|c|c|c|}
\hline \multicolumn{6}{|c|}{ Nilai Rating } \\
\hline No & Kekuatan & 4 & 3 & 2 & 1 \\
\hline 1 & Ketersediaan lahan. & \multirow{6}{*}{$\sqrt{ }$} & \multirow[b]{2}{*}{1} & & \\
\hline 2 & $\begin{array}{l}\text { Tesedianya tenaga kerja yang bersumber } \\
\text { dari dalam keluarga. }\end{array}$ & & & & \\
\hline 3 & Kesuburan Tanah & & \multirow[b]{2}{*}{$\sqrt{ }$} & & \\
\hline 4 & $\begin{array}{l}\text { Lokasi pedagang pengepul yang } \\
\text { berdekatan dengan lokasi petani. }\end{array}$ & & & & \\
\hline 5 & Pengelolaan kebun yang relatif mudah & & $\sqrt{ }$ & & \\
\hline \multirow[t]{2}{*}{6} & Adanya Kelompok Tani & & $\sqrt{ }$ & & \\
\hline & Kelemahan & 4 & 3 & 2 & 1 \\
\hline 1 & Kelemahan & & & $\sqrt{ }$ & \\
\hline & Keterbatasan modal yang dimiliki oleh & & & & \\
\hline 2 & petani & & & $\sqrt{ }$ & \\
\hline 3 & Bibit yang digunakan tidak unggul & & & & \\
\hline & Petani belum mampu mengolah karet & & & $\sqrt{ }$ & \\
\hline 4 & lebih lanjut & & & & \\
\hline 5 & Rendahnya Pendidikan Petani & & & $\sqrt{ }$ & $\sqrt{ }$ \\
\hline 6 & $\begin{array}{l}\text { Pembinaan Petani Karet } \\
\text { Belum Ada Program Peremajaan }\end{array}$ & & & $\sqrt{ }$ & \\
\hline
\end{tabular}

Sumber : Data primer diolah 2019

\section{Perumusan Strategi Alternatif}

a) Matriks IFAS

Setelah diketahui faktor-faktor internal pengembangan perkebunan karet rakyat di Desa Margahayu yang menjadi kekuatan dan kelemahan, maka selanjutnya dilakukan pemberian bobot dan rating terhadap masing-masing faktor. Nilai skor yang diperoleh dapat memberi gambaran tentang faktor strategis yang menjadi kekuatan dan kelemahan utama bagi pengembangan perkebunan karet rakyat di Desa Margahayu.
Secara keseluruhan berdasarkan tabel 6, dapat diketahui bahwa total skor faktorfaktor strategi internal dalam pengembangan perkebunan karet di Desa Margahayu adalah 2,87. Hal ini menunjukkan bahwa pengembangan perkebunan karet rakyat di Desa Margahayu berada pada kondisi di atas rata-rata $(2,50)$ yang artinya mampu memanfaatkan kekuatan-kekuatan yang dimiliki berdasarkan hasil penilaian responden untuk mengatasi kelemahan secara optimal. 
Tabel 6. Matriks IFAS

\begin{tabular}{|c|c|c|c|c|}
\hline No & Faktor-faktor Strategi Internal & Bobot & Rating & Bobot $x$ rating \\
\hline $\begin{array}{l}3 \\
4\end{array}$ & $\begin{array}{l}\text { Kekuatan } \\
\text { Ketersediaan lahan. } \\
\text { Tersedianya tenaga kerja yang } \\
\text { bersumber dari dalam keluarga. } \\
\text { Kesuburan tanah } \\
\text { Lokasi pedagang pengepul yang } \\
\text { berdekatan dengan lokasi petani. } \\
\text { Pengelolaan kebun yang relatif mudah } \\
\text { dibanding dengan komoditas lainnya. } \\
\text { Adanya kelompok tani }\end{array}$ & $\begin{array}{l}0,10 \\
0,10 \\
0,11 \\
0,12 \\
0,10 \\
0,10\end{array}$ & $\begin{array}{l}4 \\
3 \\
4 \\
3 \\
3 \\
3 \\
4\end{array}$ & $\begin{array}{l}0,40 \\
0,30 \\
0,44 \\
0,36 \\
0,30 \\
0,40\end{array}$ \\
\hline & Sub Total & & & 2,20 \\
\hline $\begin{array}{l}4 \\
5 \\
6\end{array}$ & $\begin{array}{l}\text { Kelemahan } \\
\text { Keterbatasan modal yang dimiliki oleh } \\
\text { petani } \\
\text { Bibit yang digunakan tidak unggul } \\
\text { Petani belum mampu mengolah karet } \\
\text { lebih lanjut } \\
\text { Rendahnya pendidikan petani } \\
\text { Kurangnya pembinaan Petani Karet } \\
\text { Belum ada program peremajaan }\end{array}$ & $\begin{array}{l}0,05 \\
0,07 \\
0,06 \\
\\
0,05 \\
0,08 \\
0,06\end{array}$ & $\begin{array}{l}2 \\
1 \\
2 \\
2 \\
2 \\
2\end{array}$ & $\begin{array}{l}0,10 \\
0,07 \\
0,12 \\
\\
0,10 \\
0,16 \\
0,12\end{array}$ \\
\hline & Total & $\mathbf{1 , 0 0}$ & & 2,87 \\
\hline
\end{tabular}

Sumber: Data Primer Diolah, 2019

b) Matriks EFAS

Setelah diketahui faktor-faktor eksternal pengembangan perkebunan karet rakyat di Desa Margahayu yang menjadi peluang dan ancaman, maka selanjutnya dilakukan pemberian bobot dan rating terhadap masing-masing faktor

Tabel 7. Matriks EFAS

\begin{tabular}{|c|l|c|c|c|}
\hline No & Faktor-faktor Strategi Eksternal & Bobot & Rating & Bobot x Rating \\
\hline & Peluang & 0,14 & 4 & 0,56 \\
2 & Permintaan pasar & 0,12 & 4 & 0,48 \\
& Tersedianya jenis bibit dengan & & & \\
& produktivitas tinggi & 0,12 & 3 & 0,36 \\
4 & Dukungan pemerintah & 0,13 & 3 & 0,39 \\
5 & Kesempatan bermitra & 0,11 & 3 & 0,33 \\
\hline & Tersediaan teknologi & & & $\mathbf{2 , 1 2}$ \\
\hline & Aub Total & & & \\
1 & Alih fungsi lahan & 0,05 & 2 & 0,10 \\
2 & Harga pupuk dan herbisida yang mahal & 0,09 & 1 & 0,18 \\
3 & Perubahan iklim & 0,08 & 2 & 0,08 \\
4 & Gangguan hama dan penyakit & 0,08 & 2 & 0,16 \\
5 & Harga karet tidak stabil & 0,08 & & 0,16 \\
\hline
\end{tabular}




\begin{tabular}{|l|l|c|c|c|}
\hline & Sub Total & & & $\mathbf{0 , 6 8}$ \\
\hline & Total & 1,00 & & $\mathbf{2 , 8 0}$ \\
\hline
\end{tabular}

Pemberian bobot dan rating berfungsi untuk menyusun Matriks Eksternal Faktor Strategi Eksternal berkaitan dengan peluang dan ancaman yang dianggap penting. Secara keseluruhan berdasarkan tabel 7 di atas, dapat diketahui bahwa total skor faktor-faktor strategi eksternal dalam pengembangan perkebunan karet di Desa Margahayu adalah 2,80. Hal ini menunjukan bahwa pengembangan perkebunan karet di Desa Margahayu berada pada kondisi di atas rata-rata $(2,50)$ yang artinya mampu memanfaatkan peluang-peluang yang dimiliki berdasarkan penilaian responden untuk mengatasi ancaman secara optimal.

Tabel 8. Matriks IFAS dan EFAS

\begin{tabular}{ccc}
\hline Internal dan eksternal & Opportunities & Threats \\
\hline \multirow{2}{*}{ Strengths } & Strategi SO & Strategi ST \\
& $2,20+2,12$ & $2,19+0,67$ \\
& $=4,32$ & $=2,87$ \\
\hline \multirow{2}{*}{ Weaknesses } & Strategi WO & Strategi WT \\
& $0,67+2,14$ & $0,67+0,67$ \\
& $=2,79$ & $=1,34$ \\
\hline
\end{tabular}

Sumber: Data Primer Diolah,2019

Nilai yang didapatkan dari IFAS dan EFAS tersebut, selanjutnya dijelaskan dalam suatu diagram analisis SWOT seperti gambar 2 berikut.

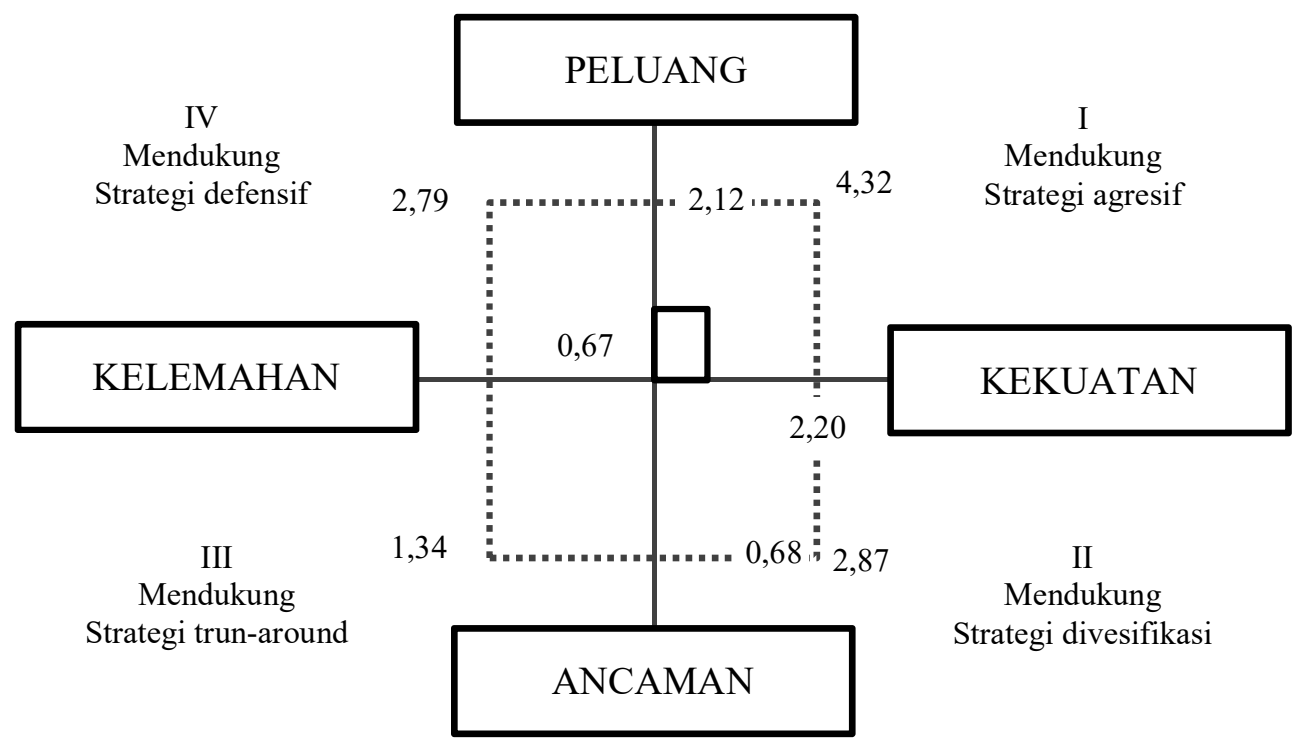

Gambar 2. Diagram Analisis SWOT Pengembangan Perkebunan Karet Rakyat di Desa Margahayu

Kuadran I :

Strategi yang harus diterapkan dalam kondisi ini adalah strategi mendukung kebijakan pertumbuhan yang agresif (Growth Oriented Strategy).

Kuadran II : 
Strategi yang harus diterapakan adalah menggunakan kekuatan untuk memanfaatkan peluang jangka panjang dengan cara strategi diversifikasi.

Kuadran III:

Fokus strategi yang dilaksanakan adalah meminimalkan masalah-masalah internal sehingga dapat merebut peluang pasar yang lebih baik atau dengan kata lain mendukung strategi trun-around. Misalkan memperbaiki mutu olahan karet . Kuadran IV:
Strategi yang harus diterapkan dalam kondisi ini adalah mendukung strategi defensif, yaitu mencari jalan keluar untuk menghadapi berbagai ancaman, memperbaiki kelemahan internal. Petani karet terus mempertahankan keberlangsungan perkebunan karet.

Hasil dari Matriks IFAS dan EFAS diatas digunakan sebagai dasar untuk menyusun Matriks SWOT yang disajikan pada Tabel 9.

Tabel 9. Matriks SWOT strategi pengembangan Perkebunan karet rakyat di Desa Margahyu.

\begin{tabular}{|c|c|c|}
\hline Internal & $\begin{array}{l}\text { Opportunities } \\
\text { 1. } \text { Permintaan pasar } \\
\text { 2. } \text { Tersedianya jenis bibit dengan } \\
\text { produktivitas tinggi } \\
\text { 3. Dukungan Permerintah } \\
\text { 4. Kesempatan bermitra } \\
\text { 5. } \text { Ketersediaan teknologi }\end{array}$ & $\begin{array}{l}\text { Threats } \\
\text { 1. Alih fungsi lahan } \\
\text { 2. Harga pupuk dan herbisida yang } \\
\text { mahal } \\
\text { 3. Perubahan iklim } \\
\text { 4. Gangguan hama dan penyakit } \\
\text { 5. Harga karet tidak stabil }\end{array}$ \\
\hline $\begin{array}{l}\text { Strengths } \\
\text { 1. Ketersediaan lahan. } \\
\text { 2. Tersedianya tenaga } \\
\text { kerja yang bersumber } \\
\text { dari dalam keluarga. } \\
\text { 3. Kesuburan tanah } \\
\text { 4. Lokasi pedagang } \\
\text { pengepul yang } \\
\text { berdekatan dengan } \\
\text { lokasi petani. } \\
\text { 5. Pengelolaan kebun } \\
\text { yang relatif mudah } \\
\text { dibanding dengan } \\
\text { komoditas lainnya. } \\
\text { 6. Adanya Kelompok } \\
\text { Tani }\end{array}$ & $\begin{array}{l}\text { Strategi SO } \\
\text { S1,S3,S5 - O1,O2: } \\
\text { Penggunaan bibit klon unggul untuk } \\
\text { menambah produktivitas tanaman karet. } \\
\text { S1,S2,S4,S6 - O2,O3,O4: } \\
\text { Menjalin kerjasama dengan pemerintah } \\
\text { ataupun swasta untuk pengembangan } \\
\text { perkebunan karet. } \\
\text { S1,S3,S6 - O1,O2,O5 } \\
\text { Memperkuat sistem informasi antara } \\
\text { anggota kelompok tani }\end{array}$ & $\begin{array}{l}\text { Strategi ST } \\
\text { S1,S3,S4,S5,S6 -T1,T2,T3,T4: } \\
\text { Menggunakan kelompok tani sebagai } \\
\text { media penguat dan media berbagi } \\
\text { informasi guna pengembangan usahatani } \\
\text { karet. } \\
\text { S2,- T2,T5: } \\
\text { Dengan tersedianya tenaga kerja dari } \\
\text { dalam keluarga, maka dapat mengurangi } \\
\text { biaya Produksi sehingga penerimaan tetap } \\
\text { besar, meskipun harga tidak stabil }\end{array}$ \\
\hline $\begin{array}{l}\text { Weaknesses } \\
\text { 1. Keterbatasan modal } \\
\text { yang dimiliki oleh } \\
\text { petani } \\
\text { 2. Bibit yang digunakan } \\
\text { tidak unggul } \\
\text { 3. Petani belum mampu } \\
\text { mengolah karet lebih } \\
\text { lanjut } \\
\text { 4. Rendahnya pendidikan } \\
\text { petani } \\
\text { 5. Kurangnya pembinaan } \\
\text { Petani Karet } \\
\text { 6. Belum ada program } \\
\text { peremajaan }\end{array}$ & $\begin{array}{l}\text { Strategi WO } \\
\text { W1,W2,W3,W5- O1,O3,O4,O5: } \\
\text { Mengajukan proposal permohonan } \\
\text { bantuan dan pendampingan. } \\
\text { W2,W3,W4,W6- O1,O2,O4,O5: } \\
\text { Menjadi anggota kelompok tani yang ada. }\end{array}$ & $\begin{array}{l}\text { Strategi WT } \\
\text { W1,T2,W3,W4,W5 - T1,T2,T3,T4: } \\
\text { Mengadakan penyuluhan dan pelatihan } \\
\text { untuk meningkatkan keterampilan petani } \\
\text { dalam pengembangan wilayah perkebunan } \\
\text { karet. } \\
\text { W3,W6 - T5 } \\
\text { Melakukan peremajaaan terhadapt } \\
\text { tanaman karet yang sudah tidak produktif } \\
\text { dengan bibit klon unggul. }\end{array}$ \\
\hline
\end{tabular}

Sumber: Data Primer Diolah, 2019 


\section{Peluang (Opportunities)}

Permintaan dan penawaran karet alam dunia dipengaruhi oleh konsumsi karet alam internasional yang disebabkan oleh adanya peningkatan/pertumbuhan industri automotif di beberapa negara seperti China. Menurut data International Rubber Study Groups (IRSG), konsumsi karet dunia diperkirakan meningkat sebesar $3,2 \%$ pada tahun 2017, sedikit di atas pertumbuhan $2,9 \%$ pada tahun 2016. Konsumsi karet dunia diperkirakan akan meningkat pada tingkat yang sedikit lebih tinggi dari 3,3\% menjadi 29,37 juta ton pada tahun 2018 di bawah skenario International Monetary Fund (IMF).

Menurut para responden permintaan akan hasil karet masih relatif besar hal ini juga ditunjang dengan keberadaan perusahan Multi Kusuma Cemerlang (PT MKC) sebagai pembeli hasil produksi karet dari petani dengan kapasitas 40 ribu ton karet pertahun. Petani dapat langsung menjual ke PT MKC sendiri merupakan anak perusahaan PT. Royal Lestary Utama joint ventureantara Barito Pasific Grup dan Michelin Grup. Michelin Grup merupakan perusahaan pembuat ban yang berada di Prancis.

Petani karet pada saat ini dengan mudah mendapatkan bibit unggul hal ini dikarenakan mudahnya petani mendapatkan informasi tentang jenis-jenis bibit unggul yang ada dipasaran, hal ini juga dipermudah dengan adanya kelompok tani dan peran pemerintah sebagai penyedia informasi tentang bibit unggul dan kelebihannya dari pada bibit yang tidak unggul. Bibit karet yang saat ini sedang dikembangkan oleh petani di Desa Margahayu jenis klon PB 260 juga merupakan satu dari beberapa varietas klon tanaman karet penghasil getah yang direkomendasikan sebagai klon karet unggul periode 2010 sampai dengan 2015.

Pemerintah Kabupaten Kutai Kartanegara sendiri sangat mendukung pengembangan perkebunan salah satunya dengan peluasan perkebunan karet rakyat dengan memberikan bantuan kepada petani berupa bibit klon unggul sebanyak 2000 bibit jenis klon PB 260 serta bantuan pupuk dan herbisida. Menurut Anwar dalam Haqiqi (2012), pembangunan ekonomi dengan pola kemitraan dapat dianggap sebagai usaha yang paling menguntungkan (maximum social benefit), terutama ditinjau dari pencapaian tujuan pembangunan jangka panjang.

\section{Ancaman}

Data dari Dinas Perkebunan Kabupaten Kutai Kartanegara pada tahun 2016-2017 tercatat 306,55 hektar lahan karet yang dialih fungsikan sebagai lahan pertambangan hal ini dikarenakan harga karet yang tidak stabil dan iming-iming dana ganti rugi yang cukup besar mengakibatkan petani karet merelakan lahannya untuk menjadi lahan pertambangan, alih fungsi lahan dapat terjadi karena rendahnya hasil pertanian yang didapatkan sedangkan biaya produksi yang cukup tinggi sedangkan hasil yang di dapatkan relatif rendah.

Dalam beberapa tahun terakhir, keadaan iklim di Kutai Kartanegara terkadang tidak menentu. Pada umumnya produktivitas karet Indonesia masih relatif rendah karena masih kurangnya penerapan teknologi budidaya karet, gangguan cuaca, iklim, gangguan dan hama penyakit. Upaya mengatasi masalah hama dan penyakit pada tanaman karet dilakukan dengan pengendalian secara terpadu untuk mendapatkan keberhasilan pengendalian yang secara ekonomi menguntungkan.

Harga karet dunia juga mempengaruhi harga karet di tingkat petani dari hasil wawancara dengan responden menyebutkan bahwa harga karet pada tahun

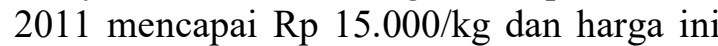
menurut petani harga tertinggi pada saat itu sedangkan pada tahun 2017 sampai dengan 2018 harga karet hanya mencapai Rp 8000 $\mathrm{Rp} 10.000 / \mathrm{kg}$.

\section{Kekuatan ( Strengths)}

Petani di Desa Margahayu sebagian besar menggunakan lahan pasca tambang 
untuk bertani maupun menanam tanaman perkebunan seperti karet dan sawit karena sebagian besar lahan yang ada di Desa Margahayu adalah lahan pasca tambang batu bara. Lahan yang diperkirakan masih dapat diolah oleh masyarakat biasanya akan diolah kembali agar lahan tersebut dapat produktif kembali.

Data yang didapatkan dari petani karet dan kepala Desa Margahayu menyebutkan rata-rata petani karet saat proses penyadap dibantu oleh keluarga dari pertaninya sendiri biasanya keluarga yang membantu saat penyadapan adalah istri, dari petani tersebut, hanya beberapa orang saja yang menggunakan pekerja dari luar keluarga hal ini dikarenakan untuk mengurangi biaya produksi.

\section{Kelemahan (Weaknesses)}

Keterbatasan modal awal menyebabkan pengembangan usahatani karet yang ada di Desa Margahayu terhambat. Data yang diperoleh dari responden petani dan petugas dari UPT Dinas Perkebunan Kecamatan Loa Kulu menyebutkan sebagian petani karet yang ada di Desa Margahayu hanya mengandalkan bantuan yang diberikan oleh Pemerintah Daerah mereka berpendapat bahwa harga bibit ataupun pupuk sangatlah mahal dan mereka tidak mampu membelinya, tetapi adapula petani yang mencari alternatif lain selain mengharap bantuan dari pemerintah para petani ini mencari bibit karet yang akan ditanam dari semaian biji karet yang berasal dari perusahaan Hasfram, tidak sedikit juga petani yang membeli bibit karet dari para pedagang. Perbedaan antara klon unggul dan tidak adalah dari potensi tanaman karet untuk memproduksi lateks tanaman karet bukan klon unggul tanpa perawatan yang baik akan sedikit menghasilkan lateks, klon unggul juga memiliki kekebalan yang tinggi terhadapa penyakit selain itu tanaman karet yang bukan dari klon unggul membutuhan waktu relatif cukup lama dibandingkan dengan tanaman karet klonunggu dalam menentukan matang sadap.

Petani yang di Desa Margahayu sebagian besar menjual hasil karetnya berbentuk lump yang masih memiliki kadar air yang cukup tinggi hanya sebagian petani yang melakukan penjemuran kepada lump sebelum dijual kepabrik atau kepengepul dengan harga berkisar $\mathrm{Rp}$ 7000- Rp $10.000 / \mathrm{kg}$.Kurangnya pengetahuan petani untuk pengolahan lump menjadi sheet membuat petani hanya menjual bahan olahan berbentuk lump sedangkan jika lump di olah menjadi sheet terlebih dahulu sebelum dijual maka harga yang akan di terima oleh petani akan semakin besar karena untuk harga sheet sendiri dihargai Rp 15.000 - Rp16.000/kg.

Pendampingan dan pembimbingan dalam budidaya karet sangatlah berperan penting dalam keberhasilan suatu usahatani dengan adanya pendampingan dan pembinaan petani yang baik akan menghasilkan produksi dan pengolahan yang lebih baik, saat ini untuk penyuluh perkebunan sendiri di Kabupaten Kutai Kartanegara hanya ada 3 orang hal ini membuat proses pendampingan kurang bisa berjalan dengan baik.

Peremajaan tanaman karet di Desa Margahayu dilakukan kepada tanaman karet yang berasal dari biji dengan tanaman karet yang berasal dari tanaman karet okulasian hal ini dilakukan karena petani beranggapan bahwa tanaman yang berasal dari biji tidak produktif dan terkadang tidak menghasilkan getah sama sekali hal ini yang membuat petani karet mulai meremajakan tanaman karetnya dengan menggunakan tanaman karet bibit unggul.

\section{Analisis Penentuan Strategi}

Analisis Matriks SWOT selanjutnya dilakukan Model Analisis Kuantitatif SWOT untuk merumuskan strategi yang nantinya dipakai sebagai alternatif dalam pengembangan perkebunan karet rakyat. 
Tabel 10. Matriks Kuantitatif SWOT

\begin{tabular}{|c|c|c|}
\hline sternal Internal & $\begin{array}{l}\text { Opportunites } \\
(2,12)\end{array}$ & $\begin{array}{c}\text { Thearts } \\
(0,67)\end{array}$ \\
\hline $\begin{array}{l}\text { Strengths } \\
\quad(2,20)\end{array}$ & $\begin{array}{l}\text { Strategi SO } \\
\text { nggunakan kekuatan internal untuk }\end{array}$ & $\begin{array}{l}\text { Strategi ST } \\
\text { kekuatan internal } \\
\text { ancaman eksternal } \\
\quad \text { secara } \\
\quad=2,87\end{array}$ \\
\hline $\begin{array}{c}\text { Weaknesses } \\
(0,67)\end{array}$ & 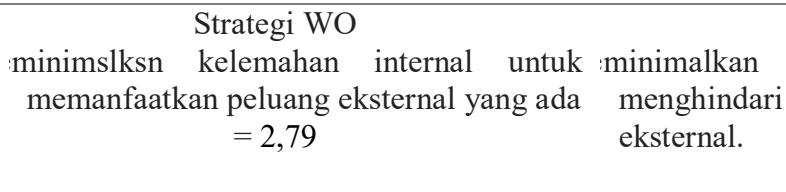 & $\begin{array}{l}\text { Strategi WT } \\
\text { kelemahan internal untuk } \\
\text { dan mengatasi ancaman } \\
\quad=1,34\end{array}$ \\
\hline
\end{tabular}

Hasil dari Tabel 10. Matriks Kuantitatif SWOT diatas menunjukkan bahwa pengembangan perkebunan karet di Desa Margahayu Kecamatan Loa Kulu, aternatif yang paling tepat,yaitu dengan menggunakan Strategi SO (Strengths and Opportunites),karena strategi tersebut mempunyai nilai yang tinggi,yaitu 4,32. Dimana pada strategi SO ialah strategi yang menggunakan kekuatan untuk memanfaatkan peluang agar para petani karet mampu mengembangkan perkebunan karet di Desa Margahayu Kecamatan Loa Kulu,dengan alternatif strategi sebagai berikut :

a. Penggunaan bibit klon unggul untuk menambah produktivitas tanaman karet.

b. Menjalin kerjasama dengan pemerintah ataupun swasta untuk pengembangan perkebunan karet.

c. Memperkuat sistem informasi antara anggota kelompok tani.

\section{KESIMPULAN DAN SARAN}

\section{Kesimpulan}

Berdasarkan hasil identifikasi dan pembahasan yang telah di jabarkan. Dapat disimulkan bahwa :

1. Faktor IFAS (Internal Strategic Faktors Analysis Summary) dalam pengembangan perkebunan karet di Desa Margahayu Kecamatan Loa Kulu Kabupaten Kutai Kartanegara yang menjadi faktor kekuatan utama adalah kesuburan tanah, kesediaan lahan, adanya kelompok tani, lokasi pedagang pengepul yang berdekatan dengan lokasi petani, pengelolaan kebun yang relatif mudah dibanding dengan komoditas lainnya, tersedianya tenaga kerja yang bersumber dari dalam keluarga. Sedangkan yang menjadi faktor kelemahan utama adalah kurangnya pembinaan petani karet petani belum mampu mengolah karet lebih lanjut, belum adanya program peremajaan, keterbatasan modal yang dimiliki oleh petani,

2. Faktor EFAS (External Strategic Factors Analysis Summary) dalam pengembangan perkebunan karet di Desa Margahayu Kecamatan Loa Kulu Kabupaten Kutai Kartanegara yang menjadi peluang utama adalah permintaan pasar yang tinggi, tersedianya jenis bibit dengan produktivitas tinggi, kesempatan bermitra, dukungan pemerintah, kesediaan teknologi. Sedangkan yang menjadi faktor ancaman utama adalah harga pupuk dan herbisida yang mahal gangguan hama dan penyakit, harga karet yang tidak setabil, alih fungsi lahan, perubahan iklim.

3. Alternatif strategi dalam pengembangan perkebunan karet rakyat di Desa Margahayu Kecamatan Loa Kulu 
Kabupaten Kutai Kartanegara dengan menggunakan kekuatan yang memanfaatkan peluang (SO) yaitu penggunaaan bibit unggul untuk menambah produktivitas tanaman karet, menjalin kerja sama dengan pemerintah ataupun swasta untuk pengembangan perkebunan karet, memperkuat sistem informasi antara anggota kelompok tani.

\section{Saran}

Berdasarkan penelitian yang dilakukan, dilakukan dapat dikemukakan beberapa saran anatara lain:

1. Melakukan pembinaan terhadap petani karet, guna melatih para petani untuk mengolah hasil karenya terlebih dahulu sebelum menjualnya.

2. Meningkatkan peran kelompok tani dalam pengembangan tanaman karet agar berkelanjutan.

3. Pengelolaan lahan pasca tambang sebagai lahan tanam bagi peluasan lahan karet masyarakat yang ada di Desa Margahayu.

4. Perlunya dukungan dan kerja sama dari berbagai pihak seperti pemerintah, perusahaan swasta dan masyarakat setempat untuk pengembangan tanaman karet yang ada di Desa Margahayu.

\section{DAFTAR PUSTAKA}

Budiman, Haryanto. 2012. Budidaya Karet unggul, Prospek Jitu Insvestasi Masa Depan. Pustaka Baru Press. Yogyakarta

BPP Kecamatan Loa Kulu. 2017. Programa Penyuluhan Pertanian Desa Margahayu Kecamatan Loa Kulu.

DISBUN Kalimantan Timur. 2017. Komoditi Karet Kalimantan Timur 2016. http://disbun.kaltimprov.go.id/ diakses pada tanggal 31 Mei 2018.

Hermy, Yulian E. 2015. Optimasi Alokasi Faktor Produksi Pada Usahatani Karet Rakyat (Studi Kasus Di
Kecamatan Lambu Kibang, Kabupaten Tulang Bawang Barat). Skripsi. Universitas Lampung, Bandar Lampung. http://digilib.unila.ac.id/10587/. 31 Mei 2018.

Haqiqi, Muhammad Ikhasan. 2012.Pola Kemitraan Pemerintah Kota Bandar Lampung Dengan PT. Perkebunan Nusantara Vii (Persero)(Studi Program Kemitraan Dan Bina Lingkungan (PKBL) Pada Pengrajin Keripik Di Sentra Industri Keripik Jalan Pagar Alam Bandar Lampung). Skripsi. Universitas Lampung, Bandar Lampung. http://digilib.unila.ac.id/10920/. 20 Oktober 2018

Nurhakim,Yusnu Iman, dan Hani,Aditya. 2014. Perkebunan Karet Skala Kecil Cepat Panen Secara Otodidak. Infra Pustaka. Depok.

Nurhafifah, Siregar, E.B.M., Siregar, T.H.S. 2011. Strategi Pengembangan Komoditi Karet di Kabupaten Tapanuli Selatan. Laporan Penelitian. Universitas Sumatera Utara. Medan. http://ojs.uma.ac.id/index.php/agrica. 20 Oktober 2018

Pearce II, John A. \& Robinson Richard B.Jr. (2008). Manajemen Strategis. Salemba Empat. Jakarta.

Rahmansyah, Tika. 2017. Peranan International Tripartite Rubber Council Terhadap Industri Karet Indonesia. Laporan Penelitian. Universitas Hasanuddin. Makassar. https://bit.ly/2090f97. $20 \quad$ Oktober $\underline{2018}$

Rangkuti, Freddy. 2006.Analisis Swot Teknik Membedah Kasus Bisnis. 
Gramedia Pustaka Utama. Jakarta

Siagian, Nurhawaty. 2015. Cara Modern Mendongkrak Produktivitas Tanaman Karet. AgroMedia Pustaka. Jakarta
Suratiyah, Ken. 2008. Ilmu Usahatani (Edisi Revisi). Penebar Swadaya.Jakarta.

Tim Penebar Swadaya. 2008. Panduan Lengkap Karet. Penebar Swadaya. 